\title{
Pengembangan LKPD Larutan Penyangga Berbasis Guided Discovery Learning dengan Tiga Level Representasi Kimia untuk Kelas XI SMA
}

\author{
A Arta ${ }^{1}$ and M Azhar ${ }^{*}$ \\ ${ }^{1}$ Pendidikan Kimia, Universitas Negeri Padang, Jl. Prof. Dr. Hamka Air Tawar \\ Padang, Sumatera Barat 25171, Indonesia \\ *minda@fmipa.unp.ac.id
}

\begin{abstract}
LKPD are one of the learning materials that can be used in the learning process. Buffer solution LKPD based on guided discovery learning with three levels chemistry representation. The type of this research was Research and Development (R\&D) with the 4D development model. 4-D models that consist of four steps: define, design, develop, and disseminate. The research was limited on develop step. The research instrument that used questionnaire in the form of validity and practicality sheet. The LKPD was validated by three UNP chemistry lectures and two chemistry teachers of SMAN 5 Padang. The LKPD was practicalited by two chemistry teachers and 28 students XII MIPA 1 of SMAN 5 Padang. Data were analyzed by Cohen's Kappa formula. The result of validity test showed that the LKPD had a very high validity category $(\mathrm{k}=$ $0,86)$. Practicality test result showed that the LKPD has very high practicality category $(\mathrm{k}=0,80$ dan $\mathrm{k}=0,82$ ). The LKPD was valid and practical.
\end{abstract}

\section{Pendahuluan}

Ilmu kimia adalah ilmu yang mempelajari tentang komposisi, sifat dan perubahan yang menyertai materi [1]. Tiga aspek penting yang merupakan karakteristik dari ilmu kimia adalah kimia sebagai produk yang berupa fakta, konsep, prinsip, hukum, dan teori; kimia sebagai proses; dan kimia sebagai sikap [2]. Larutan Peyangga merupakan salah satu pokok bahasan kimia yang dipelajari pada kelas XI SMA/MA. Materi ini mempelajari tentang konsep larutan peyangga, komponen larutan peyangga, perhitungan $\mathrm{pH}$ larutan penyangga, dan peranan larutan peyangga dalam kehidupan. Larutan penyangga adalah salah satu materi yang cukup kompleks karena berkaitan dengan dasar-dasar asam basa, proses titrasi asam basa ,perhitungan $\mathrm{pH}$, dan aplikasinya dalam kehidupan sehari-hari [3].

Pembelajaran larutan penyangga sebaiknya menerapkan tiga level representasi kimia (makroskopik, mikroskopik dan simbolik) yang dapat memudahkan peserta didik untuk memahami konsep kimia secara utuh [4]. Pembelajaran kimia berbasis tiga level representasi dapat meningkatkan prestasi belajar siswa daripada pembelajaran yang hanya menggunakan level makroskopik dan simbolik [5]. Pada umumnya pembelajaran kimia saat ini hanya menggambarkan dua level yaitu level makroskopik dan simbolik dan belum menggambarkan tiga level representasi tersebut. Pada level submikroskopik tidak terlalu disinggung.

Tiga level representasi ini dapat diterapkan ke dalam bentuk bahan ajar larutan penyangga. Bahan ajar yang dilengkapi dengan tiga level representasi dapat digunakan sebagai salah satu sumber belajar di sekolah menegah atas [6]. Salah satu jenis bahan ajar yang dapat dikembangkan adalah Lembar Kerja Peserta Didik (LKPD). Pengembangan LKPD ini disusun berdasarkan model yang relevan dengan tuntutan Kurikulum 2013. Salah satu model yang sesuai adalah model Pembelajaran guided discovery learning.

Guided discovery merupakan model pembelajaran yang melatih dan membimbing peserta didik untuk belajar, memperoleh pengetahuan, dan membangun konsep-konsep yang mereka temukan untuk 
diri mereka sendiri [7]. Pengembangan LKPD larutan penyangga menggunakan model guided discovery learning ini disusun berdasarkan tahapan-tahapannya yaitu motivation and problem presentation (motivasi dan penyampaian masalah), data collection (pengumpulan data), data processing (pengolahan data), verification (verifikasi), clossure (penutup) [8].

Berdasarkan hal di atas perlu dilakukan penelitian mengenai pengembangan LKPD larutan penyangga berbasis guided discovery learning dengan menggunakan tiga level representasi kimia dan mengungkapkan tingkat validitas dan praktikalitas LKPD larutan penyangga berbasis guided discovery learning dengan menggunakan tiga level representasi kimia. Penelitian bertujuan menghasilkan LKPD larutan penyangga berbasis guided discovery learning dengan menggunakan tiga level representasi kimia untuk kelas XI SMA yang valid dan praktis.

\section{Metode Penelitian}

Jenis penelitian ini merupakan penelitian dan pengembangan atau Research and Development (R\&D). Subjek dalam penelitian ini adalah 3 orang dosen jurusan kimia FMIPA UNP, 2 orang guru kimia SMAN 5 Padang, dan 28 orang siswa Kelas XII MIPA SMAN 5 Padang. Objek pada penelitian ini adalah LKPD larutan penyangga berbasis guided discovery learning dengan menggunakan tiga level representasi kimia untuk kelas XI SMA.

Pengembangan ini menggunakan model 4-D yang terdiri dari empat tahap yaitu define (pendefinisian), design (perancangan), dan develop (pengembangan). Tahap disseminate (penyebaran) [9]. Penelitian ini dibatasi pada tahap develop (pengembangan) yaitu uji validitas dan praktikalitas terhadap LKPD yang dikembang. Uraian kegiatan yang dilakukan pada setiap tahap sebagai berikut: (1) tahap define, tahap ini terdiri dari analisis ujung depan, analisis siswa, analisis tugas, analisis konsep, dan analisis tujuan pembelajaran. (2) tahap design, tahap ini dilakukan untuk merancang LKPD larutan penyangga berbasis guided discovery learning dengan menggunakan tiga level representasi kimia. (3) tahap develop, tahap ini terdiri dari uji validitas, revisi, dan uji praktikalitas LKPD.

Jenis data pada penelitian ini data primer yang diperoleh melalui lembar validasi dan lembar praktikalitas. Lembar validasi diberikan kepada dosen kimia FMIPA UNP dan guru kimia SMA. Lembar validasi berguna untuk menilai kelayakan isi, komponen penyajian, komponen kebahasaan, dan komponen kegrafikkan dari LKPD yang dikembangkan. Lembar Praktikalitas diberikan kepada guru kimia SMA dan siswa SMA yang berguna untuk mengetahui tingkat kepraktisan dari LKPD yang dikembangkan.

Data hasil penelitian dianalisis dengan menggunak formula kappa Cohen [10]

$$
\text { moment kappa }(k)=\frac{P o-P e}{1-P e}
$$

Keterangan:

$\mathrm{k}=$ Moment kappa yang menunjukkan validitas produk.

$\rho=$ Proporsi yang terealisasi, dihitung dengan cara jumlah nilai yang diberi oleh validator dibagi jumlah nilai maksimal.

$\rho e=$ Proporsi yang tidak terealisasi, dihitung dengan cara jumlah nilai maksimal dikurangi dengan jumlah nilai total yang diberi validator dibagi jumlah nilai maksimal.

Tabel 1. Kategori keputusan berdasarkan Momen Kappa (k)

\begin{tabular}{c|c} 
Interval & Kategori \\
\hline $0,81-1,00$ & Sangat tinggi \\
\hline $0,61-0,80$ & Tinggi \\
\hline $0,41-0,60$ & Sedang \\
\hline $0,21-0,40$ & Rendah \\
\hline $0,01-0,20$ & Sangat rendah \\
\hline 0,00 & Tidak valid
\end{tabular}




\section{Hasil dan Diskusi}

\subsection{Hasil Penelitian}

Berdasarkan tujuan dan prosedur penelitian yang telah dilakukan, maka telah dihasilkan LKPD larutan penyangga berbasis guided discovery learning untuk siswa SMA. Uji validitas dan praktikalitas terhadap LKPD telah dilakukan dan diperoleh hasil validasi oleh dosen dan guru kimia serta praktikalitas oleh guru kimia dan siswa SMAN 5 Padang. Penelitian ini dirancang dengan model pengembangan perangkat pembelajaran 4-D dengan hasil sebagai berikut ini. :

3.1.1. Tahap Define. Pada tahap define (pendefinisian) diperoleh 5 data yaitu data analisis awal-akhir, analisis siswa, analisis tugas, analisis konsep, dan analisis tujuan pembelajaran.

3.1.1.1. Analisis Awal-Akhir. Data yang diperoleh berupa hasil wawancara dan hasil angket diperoleh informasi bahwa metode yang digunakan guru pada pembelajaran adalah metode ceramah,diskusi,dan tanya jawab. Bahan ajar yang digunakan berupa buku paket,LKS, power point. Bahan ajar yang digunakan dalam materi larutan penyangga belum membuat siswa terlalu memahami materi tersebut dna hanya memuat dua level representasi yaitu level makroskopik dan simbolik. Selain itu, sekitar $50 \%$ siswa masih kesulitan dalam memahami konsep menghitung $\mathrm{pH}$ larutan penyangga.

3.1.1.2. Analisis Siswa. Berdasarkan hasil wawancara dengan guru diperoleh data bahwa kemampuan akademik dan motivasi belajar siswa kelas XI secara umum tergolong sedang. Tahap perkembangan kognitif menurut Piaget bahwa anak yang berumur 12-18 tahun berada pada tahap operational formal. Pada tahap ini anak sudah mampu berpikir abstrak dan logis. Berdasarkan hal tersebut maka pembelajaran pada tingkat SMA/MA akan lebih tepat kalau diarahkan pada pembelajaran penemuan. Oleh karena itu dibutuhkan model pembelajaran yang dapat menuntun siswa untuk menemukan konsep dan membangun pengetahuannya sendiri. Untuk menerapkan model pembelajaran tersebut perlu bahan ajar yang membuat anak berperan aktif dalam belajar, salah satunya adalah LKPD.

3.1.1.3. Analisis Tugas. Berdasarkan silabus Permendikbud no. 59 tahun 2014, materi larutan penyangga berada pada kompetensi dasar (KD) 3.12 dan 4.12 sebagai berikut.

3.12 :Menjelaskan prinsip kerja, perhitungan $\mathrm{pH}$, dan peran larutan penyangga dalam tubuh makhluk hidup.

4.12 : Membuat larutan penyangga dengan $\mathrm{pH}$ tertentu.

Berdasarkan kompetensi dasar (KD) tersebut dapat dirumuskan indikator pencapaian pembelajaran sebagai berikut.

1.Menjelaskan pengertian dan komponen penyusun larutan penyangga.

2.Menjelaskan prinsip kerja larutan penyangga.

3.Menghitung $\mathrm{pH}$ larutan penyangga asam dan basa.

4.Menjelaskan peranan larutan penyangga dalam kehidupan sehari-hari.

5.Membuat larutan penyangga dengan $\mathrm{pH}$ tertentu melalui percobaan.

3.1.1.4. Analisis Konsep. Konsep utama pada materi larutan penyangga meliputi konsep larutan penyangga, larutan penyangga asam, larutan penyangga asam, larutan penyangga basa, asam lemah, basa lemah, asam konjugasi, basa konjugasi, dan kapasitas buffer.

3.1.1.5. Analisis Tujuan Pembelajaran. Tujuan pembelajan materi larutan penyangga adalah melalui LKPD berbasis guided discovery learning dengan menggali informasi dari berbagai sumber belajar penyelidikan sederhana dan mengolah informasi, diharapkan peserta didik terlibat aktif selama proses belajar mengajar berlangsung, memiliki sikap ingin tahu, teliti dalam melakukan pengamatan, serta bertanggung jawab dalam menyampaikan pendapat, menjawab pertanyaan, kritik dan saran. Peserta didik diharapkan dapat menjelaskan prinsip kerja, perhitungan $\mathrm{pH}$, dan peran larutan penyangga dalam tubuh makhluk hidup dan membuat larutan penyangga dengan $\mathrm{pH}$ tertentu.

3.1.2. Tahap Design. Pada tahap ini diperoleh LKPD larutan penyangga berbasis guided discovery 
learning dengan menggunakan tiga level representasi kimia yang telah disusun berdasarkan komponen LKPD yang terdiri dari; 1) Kover, 2) kompetensi yang akan dicapai, 3) petunjuk penggunaan LKPD, 4) peta konsep, 5) lembar kegiatan siswa, 6) lembar kerja, 7) kunci lembar kerja , 8) lembar evaluasi, 9) kunci evaluasi. Kover LKPD dan lembar kegiatan berturut-turut diamati pada Gambar 1 dan Gambar 2.

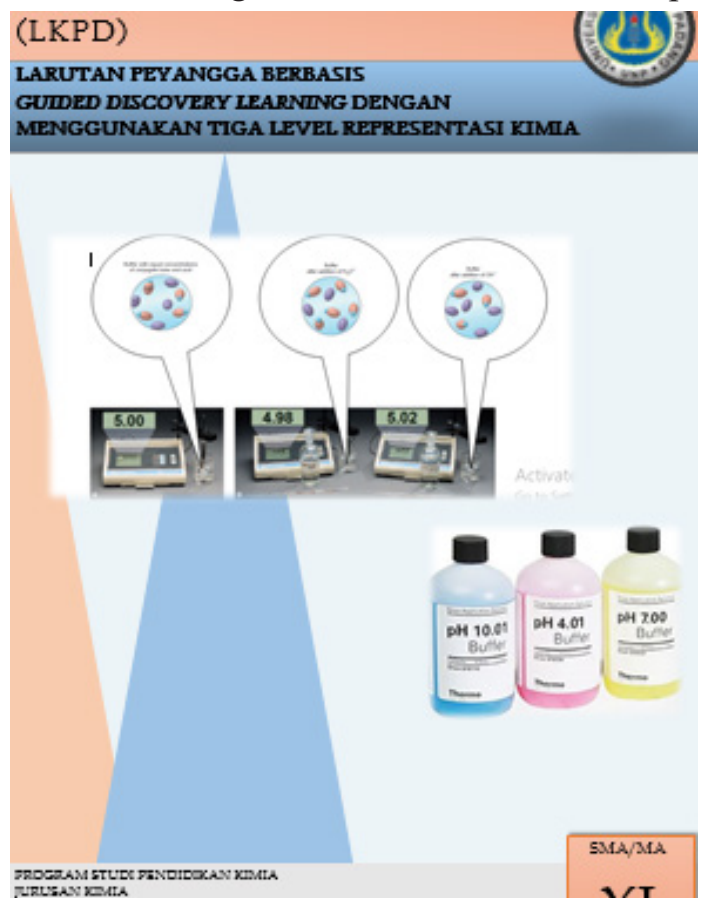

Gambar 1. Kover LKPD
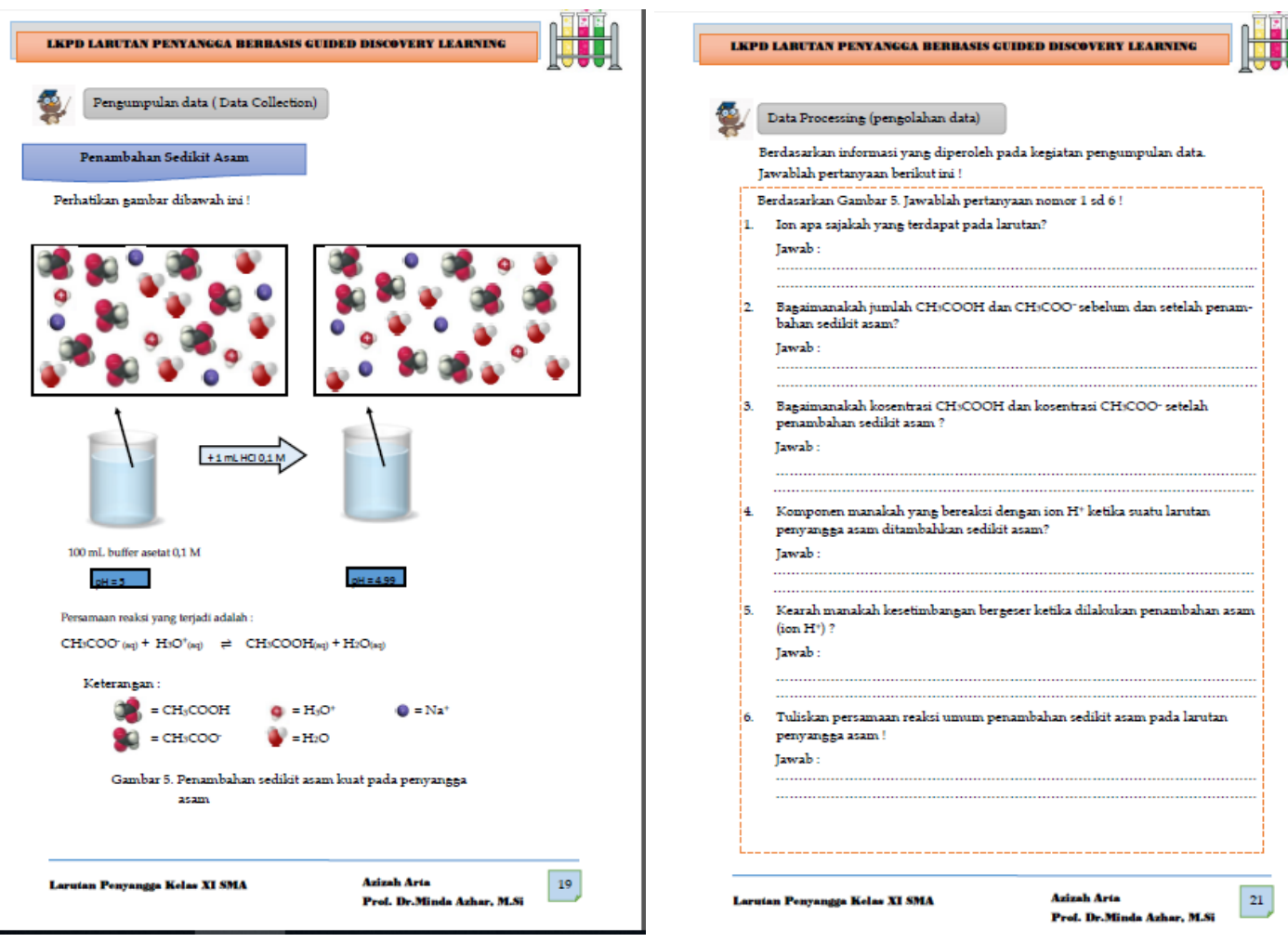

Gambar 2. Lembaran Kegiatan LKPD

3.1.1. Tahap Develop. Tahap develop (pengembangan) terdiri atas tiga langkah kegiatan, yaitu uji validitas, revisi dan uji praktikalitas. Pada tahap develop ini diperoleh data uji validitas dan uji 
praktikalitas LKPD larutan penyangga berbasis guided discovery learning dengan menggunakan tiga level representasi yang diberikan oleh dosen jurusan kimia UNP, guru kimia SMA, dan siswa kelas XII IPA.

3.1.1.1. Uji Validitas. Uji validitas terdiri dari empat komponen yaitu komponen kelayakan isi, komponen penyajian, komponen kebahasaan, dan komponen kegrafisan. Uji validitas ini bertujuan untuk mengungkapkan tingkat validitas dari LKPD larutan penyangga berbasis guided discovery learning dengan menggunakan tiga level representasi kimia yang dikembangkan.

3.1.1.2. Revisi. Tahap ini bertujuan untuk memperbaiki LKPD larutan penyangga berbasis guided discovery learning dengan menggunakan tiga level representasi kimia yang telah diberi penilaian oleh validator. LKPD yang telah direvisi diberikan lagi ke validator untuk didiskusikan kembali sebelum uji coba.

3.1.1.3. Uji Praktikalitas. Uji praktikalitas produk dilakukan kepada guru dan siswa SMAN 5 Padang kelas XII MIPA 1. Uji praktikalitas ini bertujuan untuk mengetahui praktikalitas LKPD larutan penyangga yang dikembangkan meliputi manfaat, kemudahan penggunaan, dan efisiensi waktu pembelajaran dalam menggunakan LKPD tersebut.

\subsection{Diskusi}

3.2.1. Validitas. LKPD larutan penyangga berbasis guided discovery learning dengan menggunakan tiga level representasi kimia.

Uji validitas bertujuan untuk menilai kevalidan LKPD larutan penyangga berbasis guided discovery learning dengan menggunakan tiga level representasi yang dihasilkan. Uji validitas dilakukan oleh lima orang validator yang terdiri dari 3 orang dosen kimia FMIPA UNP dan 2 orang guru kimia SMA. untuk menguji validitas konstruk instrumen, dapat digunakan pendapat ahli (judgement experts) yang jumlahnya minimal tiga orang [11]. Ada empat komponen dari LKPD larutan penyangga berbasis guided discovery learning yang dinilai oleh validator, yaitu komponen isi, komponen penyajian (konstruksi), komponen kebahasaan, dan komponen kegarfisan. Nilai rata-rata momen kappa komponen isi LKPD larutan penyangga berbasis guided discovery learning dengan menggunakan tiga level representasi kimia adalah 0,87 dengan kategori kevalidan yang sangat tinggi. Hal ini berarti materi yang terdapat di dalam LKPD larutan penyangga berbasis guided discovery learning dengan menggunakan tiga level representasi kimia ini sudah sesuai dengan tuntutan kompetensi dasar,latihan yang diberikan merupakan aplikasi langsung dari konsep yang dipelajari dan isi LKPD telah memperlihatkan tiga level representasi kimia.

Nilai rata-rata moment kappa komponen penyajian (konstruksi) LKPD larutan penyangga berbasis guide discovery learning dengan menggunakan tiga level representasi kimia adalah 0,80 dengan kategori tinggi. Hal ini menunjukkan bahwa LKPD larutan penyangga berbasis guided discovery learning ini sudah disusun berdasarkan sistematika penyusunan LKPD sesuai tahapan model guided discovery learning yaitu motivation and problem presentation, data collection, data processing, verification, dan closure [8].

Nilai rata-rata moment kappa komponen kebahasaan LKPD larutan penyangga berbasis guided discovery learning adalah 0,89 dengan kategori kevalidan sangat tinggi. Hal ini menunjukkan bahwa bahasa yang digunakan secara keseluruhan telah sesuai dengan kaidah bahasa Indonesia yang baik, jelas dan mudah dimengerti sehingga diharapkan dapat membantu siswa memahami materi larutan penyangga dengan baik.

Nilai rata-rata moment kappa komponen kegrafikaan LKPD larutan penyangga berbasis guided discovery learning dengan menggunakan tiga level representasi kimia yaitu 0,90 dengan kategori kevalidan sangat tinggi. Hal ini menunjukkan bahwa jenis dan ukuran huruf yang digunakan dalam LKPD jelas terbaca, gambar yang terdapat dalam LKPD terlihat jelas, layout teratur dan warna yang digunakan dapat menarik perhatian siswa. Nilai momen kappa secara keseluruhan dapat dilihat pada Tabel 2 . 
Tabel 2. Tabel Momen Kappa Validitas

\begin{tabular}{c|c|c|c} 
No & Aspek yang dinilai & $\begin{array}{c}\text { Rata-rata momen } \\
\text { kappa }\end{array}$ & Kategori kevalidan \\
\hline 1 & Komponen Kelayakan Isi & 0,87 & Sangat Tinggi \\
\hline 2 & Komponen Penyajian & 0,80 & Tinggi \\
\hline 3 & Komponen Kebahasaan & 0,89 & Sangat Tinggi \\
\hline 4 & Komponen Kegrafisan & 0,90 & Sangat Tinggi
\end{tabular}

Berdasarkan rata-rata momen kappa untuk keempat komponen berada pada interval 0,81-1,00 dengan kategori kevalidan sangat tinggi. Hal ini menyatakan bahwa LKPD larutan penyangga berbasis guided discovery learning dengan menggunakan tiga level representasi kimia yang dikembangkan sudah dapat digunakan dalam proses pembelajaran kimia.

3.2.2. Praktikalitas LKPD. Praktikalitas LKPD larutan penyangga berbasis guided discovery learning dengan menggunakan tiga level representasi kimia juga ditentukan oleh hasil angket respon guru dan angket respon siswa. Berdasarkan analisis data hasil uji praktikalitas guru dan siswa diperoleh nilai rata-rata moment kappa sebesar 0,80 dan 0,82 dengan kategori praktikalitas sangat tinggi. Interpretasi keseluruhan terhadap praktikalitas LKPD larutan penyangga berbasis guided discovery learning dengan menggunakan tiga level representasi kimia yang direspon siswa adalah memudahkan siswa memahami dan mengingat konsep-konsep pada materi larutan penyangga, pertanyaan dapat membimbing siswa menemukan konsep, warna gambar dan tabel pengamatan dapat menarik perhatian siswa. Hal ini menunjukkan LKPD larutan penyangga berbasis guided discovery learning dengan menggunakan tiga level representasi kimia praktis digunakan dalam proses pembelajaran. Karena pertimbangan praktikalitas dapat dilihat dari aspek-aspek kemudahan penggunaan, waktu yang diperlukan dalam pelaksanaan dan daya tarik bahan ajar terhadap minat siswa [12]. Secara keseluruhan nilai momen kappa yang diberikan guru dan siswa dapat dilihat pada Tabel 3 .

Tabel 3. Tabel Momen Kappa Praktikalitas

\begin{tabular}{c|c|c|c} 
No & Aspek yang dinilai & $\begin{array}{c}\text { Rata-rata moment } \\
\text { kappa } \\
\text { (Guru) }\end{array}$ & $\begin{array}{c}\text { Rata-rata moment kappa } \\
\text { (Siswa) }\end{array}$ \\
\hline 1 & $\begin{array}{c}\text { Komponen Kemudahan Penggu- } \\
\text { naan }\end{array}$ & 0,90 & 0,82 \\
\hline 2 & Komponen Efisiensi Waktu & 0,67 & 0,80 \\
\hline 3 & Komponen Manfaat & 0,76 & 0,84
\end{tabular}

Hal ini menunjukan bahwa LKPD larutan penyangga berbasis guided discovery learning dengan menggunakan tiga level representasi kimia untuk kelas XI SMA telah praktis.

\section{Kesimpulan}

Berdasarkan penelitian yang telah dilakukan, maka telah dihasilkan LKPD larutan penyangga berbasis guided discovery learning dengan menggunakan tiga level representasi untuk kelas XI SMA dengan menggunakan model pengembangan four-D. LKPD yang dihasilkan sudah diuji kevalidan dan kepraktisannya. Berdasarkan analisis data, diperoleh pada uji validitas nilai moment kappa sebesar 0,86 dengan kategori kevalidan yang sangat tinggi dan pada uji praktikalitas diperoleh nialai moement kappa pada guru dan siswa yaitu 0,80 dan 0,82 dengan kategori kepraktisan yang tinggi dan sangat tinggi. Berdasarkan hasil uji validitas dan praktikalitas dapat disimpulkan bahwa LKPD larutan penyangga berbasis guided discovery learning telah valid dan praktis.

\section{Referensi}

[1] Brady, James E. (2012). Chemistry Matter and Its Changes. New York: John Wiley \& Sons, Inc..

[2] BSNP. 2006. Permendiknas RI No. 22 Tahun 2006 tentang Standar Isi untuk Satuan Pendidikan

EduKimia 2019 • Volume 1 Issue 1 
Dasar dan Menangah. Jakarta Departemen Pendidikan Nasional. (2008). Pengembangan Bahan Ajar. Jakarta: Departemen Pendidikan Nasional, Direktorat Jenderal Manajemen Pendidikan Dasar dan Menengah, Direktorat Pembinaan Sekolah Menengah Atas.

[3] Setiadi, Iswan, dan Yudha Irhasyuarna. 2017. Improvement of Model Student leraning Through The Content of Solutions Guided Discovery Buffer. Journal of Research \& Method in Education. 7(1): 1-9.

[4] Gilbert, Jhon K. 2009. Multiple Representations in Chemical Education. Berlin, Germany: Springer.

[5] Herawati, Rosita Fitri, Sri Mulyani, dan Tri Redjeki. 2013. Pembelajaran Kimia Berbasis Multiple Representasi Ditinjau dari Kemampuan Awal terhadap Prestasi Belajar Laju Reaksi Siswa SMA Negeri I Karanganyar Tahun Pelajaran 2011/2012. Jurnal Pendidikan kimia (JPK). 2(2): $38-43$.

[6] Farida, Helsi, Fitriani dan M. A Ramdhani. 2017. Learning Material of Chemistry in High school using Multiple Representations: The 2nd Annual Applied science and Engineering conference (AASEC 2017).

[7] Carin, A.A. 1997. Teaching Modern Science. New York: Macmillan.

[8] Yerimadesi. 2017. Model Guided Discovery Learning untuk Pembelajaran Kimia (GDL-PK) SMA. Padang : UNP.

[9] Thiagarajan, Sivasailan, Dorothy S, Semmel, dan Melvin I. 1974. Intrutional Development for Training Teacher of Exceptional Children A sourcebook. Indian : Indiana University Bloomington.

[10] Boslaugh, Sarah dan Paul A. W. 2008. Statistis in a Nutshell, a desktop quick, reference. Beijing, Cambridge, Famham, Koln, Sebastopol, Taipei, Tokyo: O'reilly.

[11] Sugiyono. 2008. Metode Penelitian Pendidikan. Bandung: Alfabeta

[12] Sukardi. 2011. Evaluasi Pendidikan, Prinsip, Dan Operasionalnya. Yogyakarta: Bumi Aksara. 